\title{
Effect of Recombinant Surfactant Protein C-Based Surfactant on the Acute Respiratory Distress Syndrome
}

\author{
Roger G. Spragg, M.D., James F. Lewis, M.D., Hans-Dieter Walmrath, M.D., \\ Jay Johannigman, M.D., Geoff Bellingan, M.D., Pierre-Francois Laterre, M.D., \\ Michael C. Witte, M.D., Guy A. Richards, M.D., Gerd Rippin, Ph.D., \\ Frank Rathgeb, M.D., Dietrich Häfner, M.D., Friedemann J.H. Taut, M.D., \\ and Werner Seeger, M.D.
}

A BSTRACT

From the University of California at San Diego, San Diego (R.G.S.); the University of Western Ontario, London, Ont., Canada (J.F.L.); Justus Liebig-University, Giessen, Germany (H.-D.W., W.S.); the University of Cincinnati Hospital, Cincinnati (.J.); the Department of Medicine, University College London, London (G.B.); St. Luc University Hospital, Brussels (P.-F.L.); Mercy Medical Center, Des Moines, lowa (M.C.W.) University of the Witwatersrand, Johan nesburg (G.A.R.); Omnicare Clinical Research, Cologne, Germany (G.R.); and Altana Pharma, Konstanz, Germany (F.R. D.H., F.J.H.T.). Address reprint requests to Dr. Spragg at the University of California at San Diego Veterans Affairs Medical Center, 3350 La Jolla Village Dr., San Diego, CA 92014, or at rspragg@ucsd. edu, or to Dr. Seeger at werner.seeger@innere.med. uni-giessen.de.

N Engl J Med 2004;351:884-92.

Copyright $(2004$ Massachusetts Medical Society.
BACK GROUN D

Preclinical studies suggest that exogenous surfactant may be of value in the treatment of the acute respiratory distress syndrome (ARDS), and two phase 2 clinical trials have shown a trend toward benefit. We conducted two phase 3 studies of a protein-containing surfactant in adults with ARDS.

\section{METHODS}

In two multicenter, randomized, double-blind trials involving 448 patients with ARDS from various causes, we compared standard therapy alone with standard therapy plus up to four intratracheal doses of a recombinant surfactant protein C-based surfactant given within a period of 24 hours.

\section{RESULTS}

The overall survival rate was 66 percent 28 days after treatment, and the median number of ventilator-free days was 0 (68 percent range, 0 to 26); there was no significant difference between the groups in terms of mortality or the need for mechanical ventilation. Patients receiving surfactant had a significantly greater improvement in blood oxygenation during the initial 24 hours of treatment than patients receiving standard therapy, according to both univariate and multivariate analyses.

\section{CONCLUSIONS}

The use of exogenous surfactant in a heterogeneous population of patients with ARDS did not improve survival. Patients who received surfactant had a greater improvement in gas exchange during the 24-hour treatment period than patients who received standard therapy alone, suggesting the potential benefit of a longer treatment course. 
LTHOUGH EXOGENOUS SURFACTANT is of proven benefit in the prevention and treatment of the respiratory distress syndrome in infants, ${ }^{1}$ its value in treating patients with the acute respiratory distress syndrome (ARDS) has not been established. Whereas infants with an immature lung have a deficit in surfactant production, patients with ARDS have decreased surfactant production as well as biochemical alterations of endogenous surfactant that impair surface-tension-lowering properties and decreased surfactant function in distal airways. ${ }^{2}$ Normally, pulmonary surfactant phospholipids, acting in concert with surfactant proteins A, B, and C, cause alveolar surface tension to reach very low values at end expiration, thus preventing alveolar collapse. Surfactant also serves to prevent alveolar edema and maintain the patency of small airways and contributes to host defenses against microorganisms. ${ }^{3-5}$ The overall lack of surfactant function in patients with ARDS may contribute substantively to the characteristic atelectasis, shunt, and gas-exchange abnormalities and may predispose such patients to pulmonary infection and injury from mechanical ventilation.

Numerous preclinical studies and several small clinical trials have suggested that exogenous surfactant may be beneficial in the treatment of patients with ARDS. ${ }^{6-10}$ One large, double-blind, placebo-controlled trial of a nebulized, synthetic, protein-free surfactant showed no benefit, ${ }^{11}$ perhaps owing to a low level of alveolar deposition and an absence of surfactant protein. No animalderived or synthetic surfactants containing surfactant proteins have been tested in large, controlled trials. A recombinant surfactant protein $\mathrm{C}$-based surfactant that also contains phospholipids and palmitate (Venticute, Altana Pharma) has been found to have favorable results in preclinical studies, ${ }^{12,13}$ and two phase 1-2 clinical studies have shown a trend toward benefit. ${ }^{14}$ We conducted two phase 3 trials to test the hypothesis that the administration of recombinant surfactant protein C-based surfactant within a period of 24 hours would decrease the requirement for mechanical ventilation in patients with ARDS. Secondary end points included safety, the survival rate on day 28 , and oxygenation.

\section{METHODS}

STUDY DESIGN AND ENROLLMENT

We conducted two independent, multicenter, randomized, parallel-group, double-blind, controlled, prospective studies between October 1999 and September 2000. The studies were designed and analyzed by a committee of six persons, including two representatives of the sponsor. All authors had full access to the study data and contributed to the final report, and no limits on the content of the report were imposed by the sponsor. One study was conducted at 54 centers in Canada and the United States, and the other study was conducted at 55 centers in Austria, Belgium, France, Germany, the Netherlands, South Africa, Spain, Switzerland, and the United Kingdom. Both studies were performed in intensive care units treating medical patients, surgical patients, or both. The institutional review board of each center approved the study protocol, and written informed consent was obtained from each patient's next of kin or legal representative before enrollment as well as from the patient if doing so became possible during the course of the study.

Enrollment criteria included a diagnosis of ARDS according to the criteria of the AmericanEuropean Consensus Conference on ARDS ${ }^{15}$ and a requirement for endotracheal intubation and mechanical ventilation with a positive end-expiratory pressure (PEEP) of at least $5 \mathrm{~cm}$ of water. Patients with a variety of conditions associated with the development of ARDS were enrolled in the study. The events that predisposed patients to ARDS were recorded at the time of enrollment. The only difference in the design of the two studies was the timing of treatment after the diagnosis of ARDS. Treatment had to be initiated no later than 48 hours after the diagnosis in the North American study and no later than 72 hours in the European and South African study.

Patients were randomly assigned in a 1:1 ratio to receive either standard therapy for ARDS (as a control) or standard therapy plus up to four intratracheal instillations of recombinant surfactant protein C-based surfactant containing (wt/wt) 1.8 percent recombinant surfactant protein C (lusupultide), 63.4 percent 1,2-dipalmitoyl-sn-glycero3-phosphocholine, 27.8 percent 1-palmitoyl-2oleoyl-sn-glycero-3-phosphoglycerol, 4.5 percent palmitic acid, and 2.5 percent calcium chloride. One randomized patient had a serious adverse event during the baseline period and was not treated.

Before treatment, patients transiently received 100 percent oxygen and were sedated or sedated and paralyzed. Next, $1 \mathrm{ml}$ of recombinant surfactant protein $\mathrm{C}$-based surfactant (containing $1 \mathrm{mg}$ of recombinant surfactant protein $\mathrm{C}$ and $50 \mathrm{mg}$ of 
phospholipids) per kilogram of lean body weight was administered in a continuous stream through a weighted blinding bag, which concealed the medication, and an opaque catheter inserted into the endotracheal tube, with the distal end approximately $1 \mathrm{~cm}$ above the carina. The first half of the dose was administered during a pause in mechanical ventilation in which PEEP was maintained and the patient was in the left or right lateral decubitus position, and the second half was administered similarly several minutes later, with the patient in the opposite lateral decubitus position. The concentration, volume of administration, and administration technique were derived from preclinical experience. ${ }^{13}$ Up to three additional doses of this size were administered at 4-hour intervals within a period of 24 hours if the ratio of the partial pressure of arterial oxygen to the fraction of oxygen in inspired gas $\left(\mathrm{PaO}_{2}: \mathrm{FiO}_{2}\right)$ was in the range of 60 to $240 \mathrm{~mm}$ $\mathrm{Hg}$ and the patient remained intubated and mechanically ventilated with a PEEP of at least $5 \mathrm{~cm}$ of water.

To maintain blinding, surfactant was delivered from a syringe into the weighted blinding bag. In the control group, the blinding bags absorbed the study medication, whereas in the surfactant group, the study medication reached the patient's trachea through the opaque tubing. Instillations were followed by $20 \mathrm{ml}$ of air to clear the opaque catheter. In addition, physicians responsible for weaning patients from the ventilator were absent at the time of study-drug administration.

The use of a well-described ventilation strategy involving a low tidal volume was recommended, ${ }^{16}$ and investigators were urged not to change ventilator settings during the first 24 hours after treatment unless changes were required for the patients' safety. Patients were evaluated daily to determine whether they could be weaned from mechanical ventilation, and weaning was performed according to an established protocol. ${ }^{17}$

\section{BASELINE AND OUTCOME ASSESSMENTS}

The following variables were assessed at baseline and daily thereafter: tidal volume, PEEP, $\mathrm{FiO}_{2}$, $\mathrm{PaO}_{2}, \mathrm{PaO}_{2}: \mathrm{FiO}_{2}$, end-expiratory plateau pressure, and other ventilation variables; scores on the Acute Physiology and Chronic Health Evaluation (APACHE II) and the Sequential Organ-Failure Assessment (SOFA); and vital signs. Other assessments at baseline and during the 28-day study included measurements of hemodynamic variables, electrocardiography, blood gas measurements, and standard clinical laboratory measurements. We used the SOFA to determine the number of nonpulmonary organs that failed and to obtain an overall organ-failure score. ${ }^{18}$

The primary outcome variable was the number of ventilator-free days, defined as the number of days the patient was alive and not receiving mechanical ventilation during the 28 days after treatment. Patients who died during the 28-day study period were considered to have had 0 ventilator-free days. Patients receiving a continuous positive airway pressure of $5 \mathrm{~cm}$ of water or less were considered to be free of the need for mechanical ventilation. For patients who required reinstitution of mechanical ventilation for more than 1.5 hours, only the days before the reinstitution of mechanical ventilation were counted as ventilator-free days. Secondary outcome variables included the excess area under the time curve for $\mathrm{PaO}_{2}: \mathrm{FiO}_{2}$, calculated as the area between the linearly connected $\mathrm{PaO}_{2}: \mathrm{FiO}_{2}$ values during the first 24 hours after the first dose of surfactant and the line representing the baseline $\mathrm{PaO}_{2}: \mathrm{FiO}_{2}$ value; the percentage of patients alive on day 28; the percentage of patients successfully weaned from mechanical ventilation by day 28 ; and changes in ventilatory variables.

\section{STATISTICAL ANALYSIS}

A sample size of 110 patients per group was chosen in each of the two studies to provide each study with a statistical power of 80 percent to detect a mean $( \pm S D)$ difference between groups of $4 \pm 10$ ventilator-free days. Aside from the exclusion of the single patient who had a serious adverse event during the baseline period and was not treated, all analyses were conducted according to the intention-to-treat principle. The significance of differences between groups was evaluated with the use of the two-sided Wilcoxon test or, for normally distributed populations, Student's t-test at the 5 percent level of significance. ${ }^{19}$ The percentage of patients alive on day 28 was analyzed by a two-sided Fisher's exact test at the 5 percent level. Other categorical differences between groups were assessed with the use of the Cochran-Mantel-Haenszel test of nonzero correlation. Values are expressed as means $\pm S D$ unless otherwise noted.

We performed multivariate analyses of data from the two studies. To evaluate 28 -day survival, we used a multivariate logistic-regression model with a backward-selection procedure. ${ }^{20}$ We used 
a logistic model rather than a Cox model ${ }^{21}$ in order to identify a robust survival effect of surfactant as opposed to a brief extension of survival. Baseline factors included in the initial model were treatment group, study (North American vs. European and South African), age, sex, body-mass index (the weight in kilograms divided by the square of the height in meters), APACHE II score, $\mathrm{PaO}_{2}: \mathrm{FiO}_{2}$, PEEP, peak inspiratory pressure, $\mathrm{FiO}_{2}$, predisposing events (trauma or surgery, pancreatitis, pneumonia, aspiration, multiple blood transfusions, sepsis syndrome, or other), and an interaction between treatment group and study. Variables with P values of less than 0.10 were retained in the model; the variables of treatment and study were kept in the model regardless of their $P$ value.

To evaluate the number of ventilator-free days, we performed a multivariate Cox regression analysis. Because the distribution of the variable was highly skewed, we used a nonparametric Cox model (without censoring) rather than analysis of covariance. ${ }^{22}$ Finally, we used multivariate analysis of covariance to evaluate oxygenation as measured by the area under the $\mathrm{PaO}_{2}: \mathrm{FiO}_{2}$ time curve between baseline and 24 hours. For all multivariate models, model building was performed as described for the logistic-regression model.

\section{RES U LTS}

Although the protocols of the two trials differed with regard to the timing of therapy, the mean intervals from the time of diagnosis to enrollment were similar in the two groups $-21.7 \pm 8.3$ hours in the North American study and 23.2 \pm 14.4 hours in the European and South African study. Thus, the two studies were actually identical in design, and we present the results of each study and of the two combined.

\section{STUDY POPULATIONS}

The North American study enrolled 221 patients, and the European and South African study enrolled 227 patients. Of these 448 patients, 224 received surfactant and 224 did not. The groups were similar at baseline with respect to age, sex, vital signs, arterial blood gas measurements, ventilatory variables, and SOFA scores (Table 1). Although the mean APACHE II scores were similar in the two groups, the fraction of patients with a score above 23 was 75 percent greater in the surfactant group than in the control group $(\mathrm{P}=0.007)$ (Table 1$)$. The num- ber of patients studied per site ranged from 1 to 14 in the North American study and from 1 to 18 in the European and South African study.

The factors predisposing patients to the onset of ARDS are listed in Table 2. Sepsis was the most frequent predisposing event, followed by pneumonia and trauma or surgery. The most common diagnoses in the "other events" category were drug overdose, liver failure, pulmonary fat embolism, influenza, and septic shock. Fifty-four percent of the patients had more than one predisposing event; categories were nonexclusive. Patients with aspiration or pneumonia were considered to have ARDS as a result of a direct lung injury; all others were considered to have ARDS as a result of an indirect lung injury. Of the patients randomly assigned to receive surfactant, 91 percent received all four doses; the majority of undelivered doses were omitted because the criteria for retreatment were not met. Treatment was completed in 89 percent of the patients within 14 hours after enrollment.

\section{END POINTS}

In the North American study, treatment with surfactant significantly increased the area under the $\mathrm{PaO}_{2}: \mathrm{FiO}_{2}$ time curve, and this improvement was also significant in a univariate analysis when the data from the two studies were pooled (Table 3). In the multivariate analysis of this end point, the following variables remained in the final model: study $(\mathrm{P}=0.09)$, body-mass index $(\mathrm{P}=0.004), \mathrm{PaO}_{2}: \mathrm{FiO}_{2}$ value at baseline $(\mathrm{P}<0.001)$, and the predisposing event of pneumonia $(\mathrm{P}=0.03)$. A significant treatment effect $(\mathrm{P}=0.001)$ was observed. The mean difference in the area under the curve from baseline to 24 hours between the surfactant group and the control group was $305 \mathrm{~mm} \mathrm{Hg}$ • hour in the univariate analysis and $331 \mathrm{~mm} \mathrm{Hg} \cdot$ hour in the multivariate analysis (95 percent confidence interval, 137 to 525). The average $\mathrm{PaO}_{2}: \mathrm{FiO}_{2}$ values in the pooled group during the first 48 hours of treatment are shown in Figure 1. Between 4 and 24 hours after the first treatment, the values were significantly greater in the surfactant group than in the control group. By 48 hours after the first treatment, the values did not differ significantly between the two groups.

There was no significant difference between the groups in the distribution or median number of ventilator-free days per patient during the 28 days after treatment (Fig. 2 and Table 3). The overall median number of ventilator-free days was 0 


\begin{tabular}{|c|c|c|c|c|c|c|}
\hline \multirow[t]{2}{*}{ Characteristic } & \multicolumn{2}{|c|}{ North American Study } & \multicolumn{2}{|c|}{$\begin{array}{l}\text { European and South } \\
\text { African Study }\end{array}$} & \multicolumn{2}{|c|}{ Pooled Data } \\
\hline & $\begin{array}{l}\text { Control } \\
\text { Group } \\
(\mathrm{N}=115)\end{array}$ & $\begin{array}{l}\text { Surfactant } \\
\text { Group } \\
(\mathrm{N}=106)\end{array}$ & $\begin{array}{l}\text { Control } \\
\text { Group } \\
(\mathrm{N}=109)\end{array}$ & $\begin{array}{c}\text { Surfactant } \\
\text { Group } \\
(\mathrm{N}=118)\end{array}$ & $\begin{array}{l}\text { Control } \\
\text { Group } \\
(\mathrm{N}=224)\end{array}$ & $\begin{array}{c}\text { Surfactant } \\
\text { Group } \\
(\mathrm{N}=224)\end{array}$ \\
\hline \multicolumn{7}{|l|}{ Sex - no. (\%) } \\
\hline Male & $74(64)$ & $65(61)$ & $79(72)$ & $80(68)$ & $153(68)$ & $145(65)$ \\
\hline Female & $41(36)$ & $41(39)$ & $30(28)$ & $38(32)$ & $71(32)$ & $79(35)$ \\
\hline Age $-y r$ & $53.1 \pm 17.6$ & $56.5 \pm 17.8$ & $53.0 \pm 18.0$ & $50.6 \pm 17.5$ & $53.0 \pm 17.8$ & $53.4 \pm 17.9$ \\
\hline \multicolumn{7}{|l|}{ APACHE II score $†$} \\
\hline Median & 17 & 19 & 17 & 16.5 & 17 & 18 \\
\hline Mean & $17.9 \pm 6.6$ & $18.6 \pm 6.1$ & $16.6 \pm 5.8$ & $17.4 \pm 7.5$ & $17.2 \pm 6.3$ & $18.0 \pm 6.9$ \\
\hline$<11-\%$ & 9 & 12 & 17 & 21 & 13 & 17 \\
\hline $11-23-\%$ & 79 & 65 & 72 & 60 & 75 & 62 \\
\hline$>23-\%$ & 12 & 23 & 11 & 19 & 12 & $21 \%$ \\
\hline SOFA score $\mathbb{Z}$ & $7.2 \pm 3.3$ & $8.1 \pm 3.6$ & $8.7 \pm 3.5$ & $8.6 \pm 3.5$ & $7.9 \pm 3.5$ & $8.4 \pm 3.6$ \\
\hline Tidal volume $-\mathrm{ml} / \mathrm{kg}$ of body wt & $7.2 \pm 2.1$ & $7.5 \pm 2.3$ & $7.7 \pm 2.1$ & $7.7 \pm 2.2$ & $7.4 \pm 2.1$ & $7.6 \pm 2.2$ \\
\hline $\mathrm{P}_{\text {plat }}-\mathrm{cm}$ of water & $29.5 \pm 6.9$ & $29.9 \pm 7.9$ & $24.4 \pm 7.1$ & $26.0 \pm 7.8$ & $27.4 \pm 7.4$ & $28.2 \pm 8.5$ \\
\hline PEEP — cm of water & $10.6 \pm 3.6$ & $11.2 \pm 3.5$ & $10.7 \pm 3.1$ & $11.1 \pm 3.1$ & $10.7 \pm 3.4$ & $11.1 \pm 3.3$ \\
\hline $\mathrm{FiO}_{2}-\mathrm{mm} \mathrm{Hg}$ & $0.65 \pm 0.16$ & $0.65 \pm 0.17$ & $0.71 \pm 0.16$ & $0.70 \pm 0.17$ & $0.68 \pm 0.16$ & $0.68 \pm 0.17$ \\
\hline $\mathrm{PaO}_{2}: \mathrm{FiO}_{2}$ & $130 \pm 39$ & $132 \pm 40$ & $136 \pm 39$ & $137 \pm 40$ & $133 \pm 39$ & $136 \pm 41$ \\
\hline
\end{tabular}

* Plus-minus values are means \pm SD. $P_{\text {plat }}$ denotes end-inspiratory plateau pressure, PEEP positive end-expiratory pressure, $\mathrm{FiO}_{2}$ fraction of oxygen in inspired gas, and $\mathrm{PaO}_{2}$ partial pressure of oxygen in arterial blood.

$\uparrow$ Scores on the Acute Physiology and Chronic Health Evaluation (APACHE II) can range from 0 to 71, with higher scores indicating more severe illness.

$\checkmark \mathrm{P}=0.007$ for the comparison with pooled data for the control group.

$\int$ Sequential Organ-Failure Assessment (SOFA) scores range from 0 to 4 for each organ system, with higher aggregate scores indicating more severe organ dysfunction. We defined failing organs as those with an individual score of 3 or 4 .

(68 percent range, 0 to 26). The multivariate analysis of the pooled data with respect to this end point showed that surfactant, as compared with standard therapy, did not have a significant effect $(\mathrm{P}=0.51$; relative risk of additional mechanical ventilation, 0.94; 95 percent confidence interval, 0.78 to 1.13 ); in contrast, baseline PEEP did have a significant effect $(\mathrm{P}=0.003$; relative risk, 1.05 ; 95 percent confidence interval, 1.02 to 1.08), as did baseline peak inspiratory pressure $(\mathrm{P}=0.001$; relative risk, 1.02 ; 95 percent confidence interval, 1.01 to 1.04 ), indicating that compromised lung function was associated with fewer ventilator-free days.

The survival rate at 28 days also did not differ significantly between the groups (Table 3 ). The overall survival rate 28 days after treatment was 66 percent. In the multivariate analysis of the pooled data with respect to this end point, the following variables remained in the logistic-regression mod- el: study ( $\mathrm{P}=0.001$; odds ratio for death, $0.48 ; 95$ percent confidence interval, 0.31 to 0.74 ), reflecting a lower mortality rate in the North American study than in the European and South African studies; APACHE II score ( $\mathrm{P}=0.001$; odds ratio, 1.06 ; 95 percent confidence interval, 1.02 to 1.10 ) and age $(\mathrm{P}<0.001$; odds ratio, 1.04 ; 95 percent confidence interval, 1.02 to 1.05 ), indicating that severely ill and older patients were more likely to die than less ill and younger patients; and the baseline $\mathrm{PaO}_{2}: \mathrm{FiO}_{2}$ value $(\mathrm{P}=0.07$; odds ratio, $0.995 ; 95$ percent confidence interval, 0.989 to 1.001 ), indicating that more severely compromised lung function was associated with an increased mortality rate. No significant treatment effect was observed $(\mathrm{P}=0.54$; odds ratio, 1.14; 95 percent confidence interval, 0.74 to 1.75 ). Other clinical, physiological, and ventilatory measurements (including the SOFA score, partial pressure of carbon dioxide in arterial 


\begin{tabular}{|c|c|c|c|c|c|c|}
\hline \multirow[t]{3}{*}{ Predisposing Event } & \multicolumn{2}{|c|}{ North American Study } & \multicolumn{2}{|c|}{$\begin{array}{l}\text { European and South } \\
\text { African Study }\end{array}$} & \multicolumn{2}{|c|}{ Pooled Data } \\
\hline & $\begin{array}{l}\text { Control } \\
\text { Group } \\
(\mathrm{N}=115)\end{array}$ & $\begin{array}{l}\text { Surfactant } \\
\text { Group } \\
(\mathrm{N}=106)\end{array}$ & $\begin{array}{c}\text { Control } \\
\text { Group } \\
(\mathrm{N}=109)\end{array}$ & $\begin{array}{l}\text { Surfactant } \\
\text { Group } \\
(\mathrm{N}=118)\end{array}$ & $\begin{array}{l}\text { Control } \\
\text { Group } \\
(\mathrm{N}=224)\end{array}$ & $\begin{array}{c}\text { Surfactant } \\
\text { Group } \\
(\mathrm{N}=224)\end{array}$ \\
\hline & \multicolumn{6}{|c|}{ number (percent) } \\
\hline Sepsis & $53(46)$ & $55(52)$ & $72(66)$ & $76(64)$ & $125(56)$ & $131(58)$ \\
\hline Pneumonia & $44(38)$ & $33(31)$ & $42(39)$ & $55(47)$ & $86(38)$ & $88(39)$ \\
\hline Trauma or surgery & $30(26)$ & $34(32)$ & $38(35)$ & $33(28)$ & $68(30)$ & $67(30)$ \\
\hline Aspiration & $10(9)$ & $10(9)$ & $9(8)$ & $13(11)$ & $19(8)$ & $23(10)$ \\
\hline Multiple transfusions & $3(3)$ & $10(9)$ & $8(7)$ & $7(6)$ & $11(5)$ & $17(8)$ \\
\hline Pancreatitis & $4(3)$ & $8(8)$ & $5(5)$ & $5(4)$ & $9(4)$ & $13(6)$ \\
\hline Burn injury & $2(2)$ & $2(2)$ & $1(1)$ & $1(1)$ & $3(1)$ & $3(1)$ \\
\hline Direct toxic injury to the lung & $1(1)$ & $1(1)$ & 0 & 0 & $1(<1)$ & $1(<1)$ \\
\hline Other events & $25(22)$ & $16(15)$ & $21(19)$ & 20 (17) & $46(21)$ & $36(16)$ \\
\hline
\end{tabular}

* Fifty-four percent of the patients had more than one predisposing event.

\begin{tabular}{|c|c|c|c|c|c|c|}
\hline \multirow[t]{2}{*}{ Outcome } & \multicolumn{2}{|c|}{ North American Study } & \multicolumn{2}{|c|}{$\begin{array}{l}\text { European and South } \\
\text { African Study }\end{array}$} & \multicolumn{2}{|c|}{ Pooled Data } \\
\hline & $\begin{array}{l}\text { Control } \\
\text { Group } \\
(\mathrm{N}=115)\end{array}$ & $\begin{array}{l}\text { Surfactant } \\
\text { Group } \\
(\mathrm{N}=106)\end{array}$ & $\begin{array}{l}\text { Control } \\
\text { Group } \\
(\mathrm{N}=109)\end{array}$ & $\begin{array}{l}\text { Surfactant } \\
\text { Group } \\
(\mathrm{N}=118)\end{array}$ & $\begin{array}{l}\text { Control } \\
\text { Group } \\
(\mathrm{N}=224)\end{array}$ & $\begin{array}{c}\text { Surfactant } \\
\text { Group } \\
(\mathrm{N}=224)\end{array}$ \\
\hline $\begin{array}{l}\text { Ventilator-free days } \\
\text { Median } \\
68 \% \text { range }\end{array}$ & $\begin{array}{c}6.0 \\
0.0-21.0\end{array}$ & $\begin{array}{c}3.5 \\
0.0-21.0\end{array}$ & $\begin{array}{c}0.0 \\
0.0-20.0\end{array}$ & $\begin{array}{c}0.0 \\
0.0-19.0\end{array}$ & $\begin{array}{c}1.0 \\
0.0-20.0\end{array}$ & $\begin{array}{c}0.0 \\
0.0-20.0\end{array}$ \\
\hline $\begin{array}{l}\text { Area under } \mathrm{PaO}_{2}: \mathrm{FiO}_{2} \text { time curve from } \\
\text { baseline to } 24 \mathrm{hr}(\mathrm{mm} \mathrm{Hg} \cdot \mathrm{hr}) *\end{array}$ & $417 \pm 984$ & $809 \pm 1397 \dagger$ & $319 \pm 802$ & $554 \pm 1052 \%$ & $369 \pm 900$ & $674 \pm 1229 \mathbb{1}$ \\
\hline Alive at day 28 (\%) & 75 & 68 & 61 & 61 & 68 & 64 \\
\hline \multicolumn{7}{|c|}{$\begin{array}{l}* \text { The values are empirical means } \pm S D \text {. } \\
\dagger P=0.02 \text { for the comparison with the control group by the } t \text {-test in a univariate analysis. } \\
\qquad P=0.06 \text { for the comparison with the control group by the } t \text {-test in a univariate analysis. } \\
\int P=0.003 \text { for the comparison with the control group by the t-test in a univariate analysis. }\end{array}$} \\
\hline
\end{tabular}

blood, $\mathrm{pH}$, peak inspiratory pressure, end-inspiratory plateau pressure, tidal volume, and PEEP) did not change significantly during the first 24 hours after the initiation of treatment.

Approximately 60 percent of the patients had adverse events in the first 24 hours after the initial treatment - a frequency consistent with the complexity and severity of their disease. During this period, 51 of the 224 patients receiving surfactant (23 percent) and 11 of the 224 patients receiving standard therapy ( 5 percent) had adverse events that were probably or definitely related to treatment $(\mathrm{P}<0.001) ; 10$ patients receiving surfactant
( 4 percent) and 4 patients receiving standard therapy ( 2 percent) had adverse events that were judged to be serious and probably or definitely related to treatment $(\mathrm{P}=0.11)$. The most common adverse events were hypoxemia, hypotension, and bradycardia.

\section{POST HOC ANALYSIS OF DIRECT}

VERSUS INDIRECT ARDS

In the subgroup of patients in the two studies with ARDS due to pneumonia, witnessed aspiration of gastric contents, or both (102 patients in the control group and 103 patients in the surfactant group), 


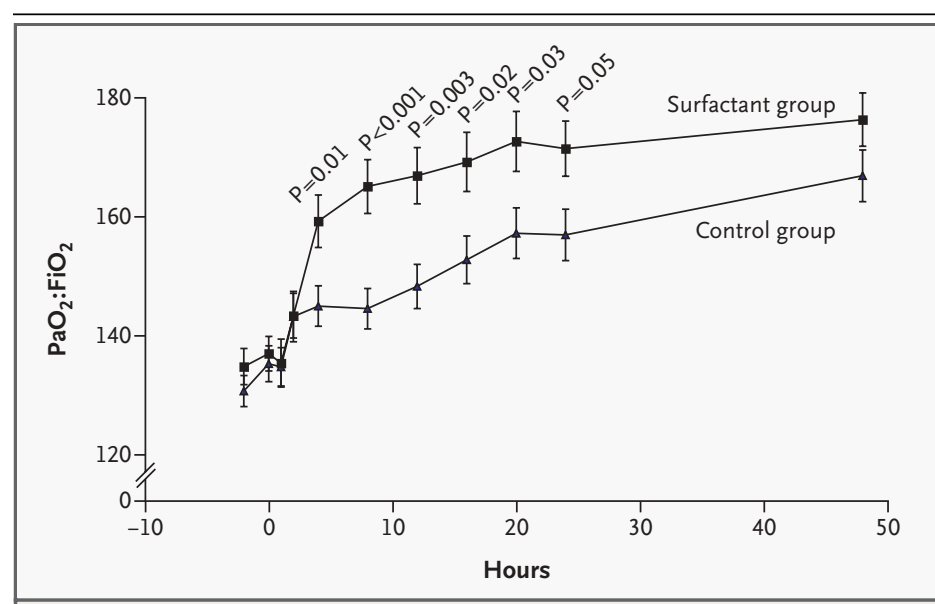

Figure 1. Mean ( $\pm \mathrm{SE}) \mathrm{PaO}_{2}: \mathrm{FiO}_{2}$ Values in the Control Group and the Surfactant Group.

The mean $\mathrm{PaO}_{2}: \mathrm{FiO}_{2}$ value, a measure of the blood-oxygenating ability of the lung, was significantly greater from 4 to 24 hours after treatment in the surfactant group than in the control group.

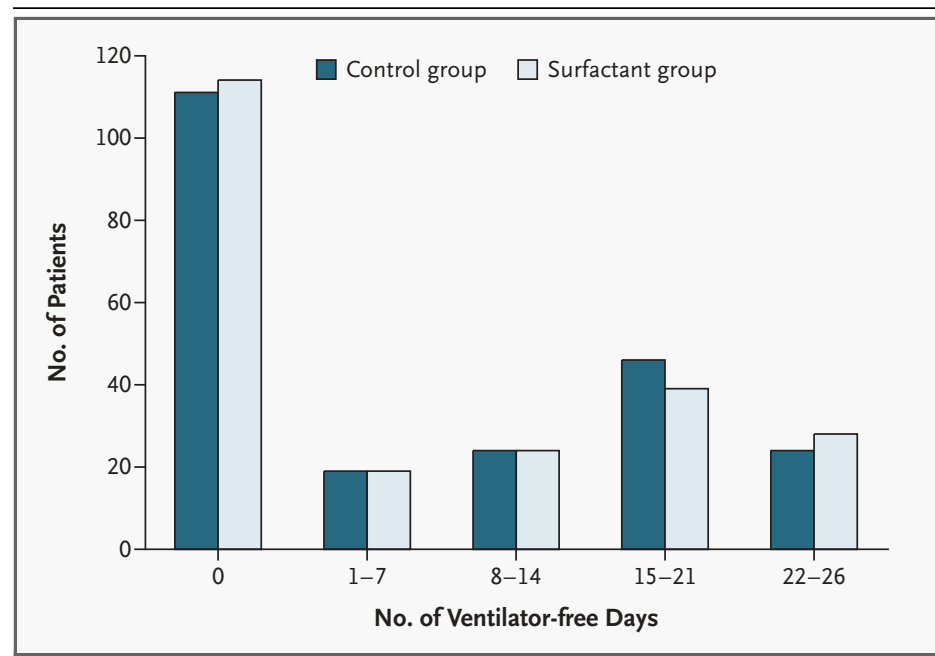

Figure 2. Number of Ventilator-free Days in the Control Group and the Surfactant Group.

Patients with 0 ventilator-free days included those who were never free from mechanical ventilation and those who died within 28 days after treatment, regardless of their need for mechanical ventilation. There were no significant differences between the two groups.

the mortality rate was 30 percent in the surfactant group and 36 percent in the control group $(\mathrm{P}=0.29$ with only the study and the treatment groups as covariates; $\mathrm{P}=0.03$ with the use of a backwardselection logistic model). The backward-selection logistic model controlled for the study $(\mathrm{P}=0.05$; odds ratio for death in the surfactant group as compared with the control group, 0.49 ; 95 percent confidence interval, 0.24 to 1.00$)$, APACHE score $(\mathrm{P}=$ 0.002; odds ratio, 1.09; 95 percent confidence interval, 1.03 to 1.15$)$, age ( $\mathrm{P}<0.001$; odds ratio, 1.05; 95 percent confidence interval, 1.03 to 1.07 ), and the presence or absence of pneumonia as a predisposing event $(\mathrm{P}=0.003$; odds ratio, 0.05 ; 95 percent confidence interval, 0.01 to 0.37 ), aspiration as a predisposing event $(\mathrm{P}=0.08$; odds ratio, 0.28 ; 95 percent confidence interval, 0.07 to 1.17$)$, and other predisposing events $(\mathrm{P}=0.10$; odds ratio, 3.63; 95 percent confidence interval, 0.80 to 16.51 ). Among patients who had ARDS as a result of indirect lung injury, the mortality rate was 41 percent among patients who received surfactant and 28 percent among those who received standard therapy ( $\mathrm{P}=0.04$ by the chi-square test).

To analyze whether there were different treatment effects among patients with direct as compared with indirect lung injury, we evaluated all models for an interaction between treatment and the cause of ARDS (direct or indirect). This interaction was significant $(\mathrm{P}=0.002)$ for the mortality analysis and did not reach significance for the analysis of the number of ventilator-free days $(\mathrm{P}=0.14)$, indicating that among patients with ARDS caused by a direct lung injury, those who received surfactant tended to have a higher survival rate than those who received standard therapy. An oxygenation benefit was found across the entire population of patients who received surfactant (Table 3 ), and thus, as expected, there was no significant interaction between the cause of ARDS and treatment $(\mathrm{P}=0.99)$. At baseline, the number of nonpulmonary organs that were failing (with failure of an organ defined as a SOFA score of 3 or 4 ) was significantly greater in the group of patients with indirect ARDS than in the group of patients with direct ARDS $(\mathrm{P}=$ 0.02) (Fig. 3).

\section{DISCUSSION}

The results of our two studies of recombinant surfactant protein C-based surfactant show that although surfactant therapy improved oxygenation, it did not increase the number of ventilator-free days or reduce mortality in a heterogeneous population of patients with ARDS. These results are somewhat unexpected, since preliminary studies showed that recombinant surfactant protein C-based surfactant, 
administered as it was in our trials, might provide clinical benefit. ${ }^{14}$

It is a frequent and unfortunate finding in intensive care studies that encouraging results from phase 2 studies are not replicated in larger, phase 3 studies. ${ }^{23}$ It is possible that there is no population, or only a very specific population, of patients with acute lung injury who will benefit from exogenous surfactant treatment. Although patients with the highest APACHE II scores were overrepresented in the surfactant group as compared with the control group, the differences in outcome between the groups remained nonsignificant after adjustment for the severity of illness.

A distinction between ARDS associated with direct lung injury and that associated with indirect injury has been proposed, ${ }^{24}$ and such a distinction might be used to define groups that are more homogeneous with respect to mechanisms of lung injury. To determine whether treatment with recombinant surfactant protein C-based surfactant might specifically benefit patients with ARDS related to direct lung injury, we performed a post hoc analysis of patients with ARDS due to pneumonia, aspiration, or both - processes with pathophysiological mechanisms that primarily affect the lung. The interaction between treatment and the mechanism of lung injury was significant in the mortality analysis, suggesting that among patients with direct ARDS, patients who received surfactant tended to have higher survival rates than patients who received standard therapy. These observations suggest that whereas surfactant treatment may improve oxygenation in patients with various predisposing factors for ARDS, patients with direct lung injury and fewer severe coexisting conditions also derive a survival benefit. Patients with indirect lung injury form an extremely heterogeneous group. The post hoc analysis showing worsened survival among patients who received surfactant has no clear explanation and must be viewed with caution.

Were the type of exogenous surfactant and the dosing schedule adequate? Studies comparing various surfactants indicate that recombinant surfactant protein C-based surfactant has excellent properties in animal models of acute lung injury, despite the absence of other surfactant-associated proteins. ${ }^{12,25}$ The dosing schedule we used resulted in most patients' receiving all four doses of surfactant within 12 hours after enrollment. In other trials, patients have received up to eight doses, ${ }^{7}$ or the re-

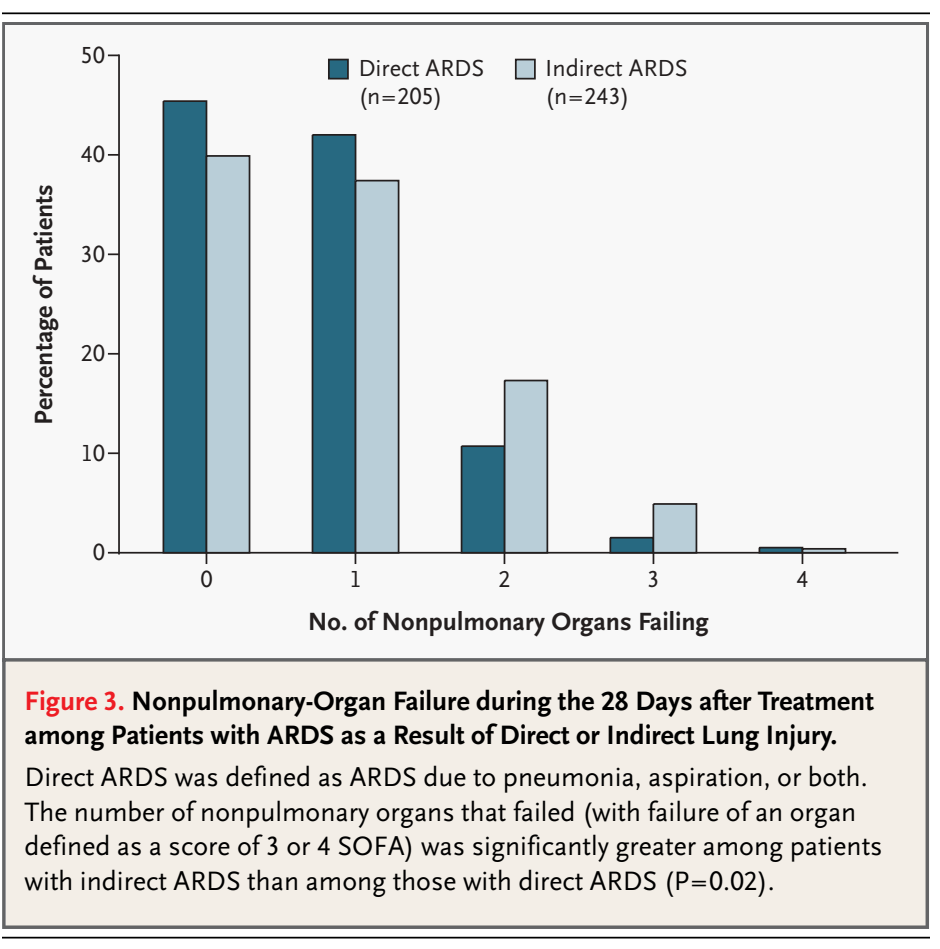

peated administration of surfactant has been left to the investigators' discretion during a treatment period lasting several days. ${ }^{10}$ Indeed, on the basis of oxygenation data in our studies, we suspect that our treatment window might have been too narrow. Improvements in oxygenation in certain subgroups of treated patients tended to decline 12 hours or more after the completion of the therapy. The antiinflammatory effects of surfactant treatment, as reflected by the levels of interleukin- 6 in lung-lavage fluid and plasma, are also similarly transient when treatment is confined to a 12-hour period. ${ }^{14}$ Taken together, these observations indicate the probable need for a prolonged treatment period, possibly with greater intervals between doses or with a larger number of doses than those studied thus far.

In summary, we found that oxygenation, but not outcome, improved after up to four intratracheal instillations of recombinant surfactant protein C-based surfactant within a 24-hour period in two large studies of patients with ARDS. Thus, the routine use of surfactant in the treatment of patients with ARDS is not justified.

Funded by Altana Pharma, Konstanz, Germany.

Drs. Lewis, Spragg, Seeger, and Rippin report having served as paid consultants to Altana Pharma. 
APPENDIX

The following were members of the Venticute Study Group: Austria — P. Germann, P. Schenk, H. Schöchl; Belgium — L. Bossaert, F. Colardyn, L. Hubloue, P.-F. Laterre, J.L. Vincent; Canada - P. Aslanian, A. Cooper, J. Fenwick, P. Goldberg, C. Hamielec, D. Heyland, R. Hodder, E. Jacobsohn, R. Johnston, M. Lessard, O. Lesur, J. Lewis, B. Light, I. Mayers, D. Mazer, J. Muscedere, J. Pinilla, T. Rogovein, D. Rolf, D. Wong; France - J.P. Bedos, G. Bleichner, B. Debaene, L. Holzapfel, A. Leon, G. Offenstadt, M. Ossart, J. Reignier, O. Ruyer, A. Tenaillon, F. Zeni; Germany - J. Hohlfeld, I. Klett, T. Klös, E. Kollig, M. Pfeifer, M. Ragaller, K.F. Rothe, W. Seeger, C. Spies, B.E. Strauer, T. Welte, M. Wiersbitzky; United Kingdom — R. Beale, G. Bellingan, D. Bennett, G. Findlay, K. Girling, A. Lee; the Netherlands - H. Bruining, W. Geus; South Africa - P. van den Berg, S. Bhagwanjee, J.G. Kilian, G. Naude, G. Richards, J.B. de Vaal; Spain — A. Artigas, A. Esteban, J. Gómez-Rubi, J. Ibánez, F. Latorre, J. Mancebo, J. Rello; Switzerland - R. Chiolèro, R. Malacrida, H. Pargger; United States — J. Allen, Jr., M. Apostolakos, R. Baughman, E. Cordasco, P. Edelstein, D. Frank, S. Fuhrman, K. Guntupalli, D. Heiselman, R.D. Hite, D. Ingbar, J. Johannigman, J. Kennedy, Jr., K. Kerr, S. Khalil, K. Krell, W. Kuschner, M. Massad, M. Morganroth, M. Moss, J. Ochoa, P. Offner, D. Ost, R. Ovetsky, M. Polkow, R. Powell, J. Rehm, J. Rubin, M. Rumbak, S. Shahryar, H. Silverman, T. Smith, G. Stewart, S. Stites, J. Westerman, M.C. Witte.

REFERENCES

1. Jobe AH. Pulmonary surfactant therapy. N Engl J Med 1993;328:861-8.

2. Spragg RG, Lewis JF. Surfactant therapy in the acute respiratory distress syndrome. In: Matthay MA, ed. Acute respiratory distress syndrome. New York: Marcel Dekker, 2003 533-62.

3. Walters DV. The role of pulmonary surfactant in transepithelial movement of liquid. In: Robertson B, Van Golde LMG, Batenburg JJ, eds. Pulmonary surfactant: from molecular biology to clinical practice. Amsterdam: Elsevier, 1992:193-213.

4. Enhorning G, Duffy LC, Welliver RC Pulmonary surfactant maintains patency of conducting airways in the rat. Am J Respir Crit Care Med 1995;151:554-6.

5. Wright JR. Pulmonary surfactant: a front line of lung host defense. J Clin Invest 2003; 111:1453-5.

6. Spragg RG, Gilliard N, Richman P, et al Acute effects of a single dose of porcine surfactant on patients with the adult respiratory distress syndrome. Chest 1994;105:195 202.

7. Gregory T), Steinberg KP, Spragg R, et al. Bovine surfactant therapy for patients with acute respiratory distress syndrome. Am J Respir Crit Care Med 1997;155:1309-15. 8. Wiswell TE, Smith RM, Katz LB, et al Bronchopulmonary segmental lavage with Surfaxin (KL(4)-surfactant) for acute respiratory distress syndrome. Am J Respir Crit Care Med 1999;160:1188-95.

9. Walmrath D, Günther A, Ghofrani HA et al. Bronchoscopic surfactant administration in patients with severe adult respiratory distress syndrome and sepsis. Am J Respir Crit Care Med 1996;154:57-62

10. Kesecioglu J, Schultz MJ, Lundberg D, Lauven PM, Lachmann B. Treatment of acute lung injury (ALI/ARDS) with surfactant. Am J Respir Crit Care Med 2001;165:A819. abstract.

11. Anzueto A, Baughman RP, Guntupall $\mathrm{KK}$, et al. Aerosolized surfactants in adult with sepsis-induced acute respiratory dis tress syndrome. N Engl J Med 1996;334. 1417-21.

12. Häfner D, Germann PG, Hauschke D. Effects of rSP-C surfactant on oxygenation and histology in a rat-lung-lavage model of acute lung injury. Am J Respir Crit Care Med 1998;158:270-8.

13. Spragg RG, Smith RM, Harris K, Lewi J, Häfner D, Germann P. Effect of recombinant SP-C surfactant in a porcine lavage model of acute lung injury. J Appl Physiol 2000;88:674-81.

14. Spragg RG, Lewis JF, Wurst W, et al. Treatment of acute respiratory distress syndrome with recombinant surfactant pro tein C surfactant. Am J Respir Crit Care Med 2003;167:1562-6

15. Bernard GR, Artigas A, Brigham KL, et al. The American-European Consensus Conference on ARDS: definitions, mechanisms, relevant outcomes, and clinical trial coordination. Am J Respir Crit Care Med 1994 149:818-24.

16. The Acute Respiratory Distress Syndrome Network. Ventilation with lower tida volumes as compared with traditional tida volumes for acute lung injury and the acute respiratory distress syndrome. N Engl J Med 2000;342:1301-8.

17. Ely EW, Baker AM, Dunagan DP, et al. Effect on the duration of mechanical ventilation of identifying patients capable of breathing spontaneously. N Engl J Med 1996; 335:1864-9.

18. VincentJL, de Mendonca A, Cantraine F, et al. Use of the SOFA score to assess the incidence of organ dysfunction/failure in intensive care units: results of a multicenter, prospective study. Crit Care Med 1998;26: 1793-800.

19. Hollander M, Wolfe DA. Nonparametric statistical methods. New York: John Wiley, 1973.

20. Kleinbaum DG. Logistic regression: a self-learning text. New York: Springer, 1994.

21. Idem. Survival analysis: a self-learning text. New York: Springer, 1996.

22. Johnson RA, Wichern DW. Applied multivariate statistical analysis. 5th ed. Upper Saddle River, N.J.: Prentice-Hall, 2002.

23. McIntyre RC Jr, Pulido EJ, Bensard DD, Shames BD, Abraham E. Thirty years of clinical trials in acute respiratory distress syndrome. Crit Care Med 2000;28:3314-31.

24. Ware LB, Matthay MA. The acute respiratory distress syndrome. N Engl J Med 2000; 342:1334-49.

25. Herting E, Rauprich P, Stichtenoth G, Walter G, Johansson J, Robertson B. Resistance of different surfactant preparations to inactivation by meconium. Pediatr Res 2001; 50:44-9.

Copyright (c) 2004 Massachusetts Medical Society. 